\title{
KHASIAT DAUN BINAHONG (Anredera cordifolia (Ten.) Steenis) TERHADAP PEMBENTUKAN JARINGAN GRANULASI DAN REEPITELISASI PENYEMBUHAN LUKA TERBUKA KULIT KELINCI
}

\author{
${ }^{1}$ Suci Ariani \\ ${ }^{2}$ Lily Loho \\ ${ }^{2}$ Meilany F. Durry
}

\author{
${ }^{1}$ Kandidat Skripsi Fakultas Kedokteran Universitas Sam Ratulangi Manado \\ ${ }^{2}$ Bagian Patologi Anatomi Fakultas Kedokteran Universitas Sam Ratulangi Manado \\ Email: suciarianitandung@gmail.com
}

Latar Belakang: Luka merupakan keadaan dimana kontinuitas jaringan rusak oleh karena trauma dari benda tajam atau tumpu, perubahan suhu, kimiawi, listrik, radiasi, atau gigitan hewan. Proses penyembuhan luka bisa dipercepat dengan menggunakan pengobatan tradisional, salah satunya adalah tanaman binahong (Anredera cordifolia (Ten.) Steenis). Tujuan: Untuk melihat khasiat daun binahong terhadap pembentukan jaringan granulasi dan reepitelisasi penyembuhan luka terbuka kulit kelinci secara makroskopik dan mikroskopik. Metode: Penelitian ini menggunakan metode eksperimental dengan subjek 5 ekor kelinci. Satu ekor kelinci untuk meilhat struktur jaringan kulit normal kelinci. Empat ekor kelinci dibuat luka, pada punggung kanan diberikan daun binahong dan luka pada punggung kiri tidak diberikan daun binahong. Kelompok A terdiri dari dua ekor kelinci yang diambil dan dilihat jaringan luka pada hari kelima, kelompok B terdiri dari dua ekor kelinci yang diambil dan dilihat jaringan lukanya pada hari ke-14. Hasil: Secara makroskopik luka yang diberi daun binahong terlihat lebih kecil dan kering, sedangkan yang tidak diberi daun binahong terlihat luka masih dalam, dan kemerahan. Secara mikroskopik luka yang diberi daun binahong terbentuk jaringan granulasi yang lebih banyak dan reepitelisasi lebih cepat dibandingkan dengan yang tidak diberi daun binahong. Simpulan: Pemberian daun binahong pada luka membantu penyembuhan luka dengan pembentukan jaringan granulasi yang lebih banyak dan reepitelisasi terjadi lebih cepat dibandingkan dengan luka yang tidak diberi daun binahong.

Kata Kunci: Luka terbuka, daun binahong, jaringan granulasi, reepitelisasi.

Background: Wound is a condition when the continuity of tissue are damaged by the trauma of sharp or blunt objects, temperature changes, chemicals, electricity, radiation, or animal bites. The process of wound healing can be accelerated by using traditional medicines, one of them is a plant called Binahong (Anredera cordifolia (Ten.) Steenis). Objective: To observe the influences of binahong leaf in granulation tissue formation and epithelial regeneration of an open wound healing of skin rabbit, both macroscopic and microscopic features. Method: Experimental research employed five adult rabbits as the subject: one rabbit as a control - to observe the structure of rabbit skin tissue. The four rabbits are made wounds, to the back right were given binahong leafs and wounds to the back left were not. Group A and B - two rabbits in each group. Rabbits in group A are used to observe the wounded tissue in the fifth day. Rabbits in group B are used to observe the wounded tissue in the fourteenth day. Results: The macroscopic result of wounds with binahong had smaller shape and dry, while the wound without binahong leafs are still look deeper, wet, and redness. By microscopic examination, wounds with binahong leafs formed granulation tissue and epithelial regeneration more and faster than those which not given binahong leafs. Conclusions: Binahong leafs help in healing 
the wounds with forming more granulation tissue and faster in epithelial regeneration than the wounds without binahong leafs.

Keywords: Open wounds, binahong leaf, granulation tissue, epithelial regeneration.

Tumbuhan binahong telah ribuan tahun dikenal dan dikonsumsi oleh bangsa Tiongkok, Korea, Taiwan dll. ${ }^{1}$ Tanaman binahong berasal dari Cina dan menyebar ke Asia Tenggara. Di negara Eropa maupun Amerika, tanaman ini cukup dikenal, tetapi para ahli disana belum tertarik untuk meneliti serius dan mendalam, padahal beragam khasiat sebagai obat telah diakui. Di kawasan Asia Tenggara, tumbuhan ini merupakan konsumsi wajib penduduk Vietnam ketika perang melawan Amerika. Tanaman ini mempunyai banyak khasiat dalam menyembuhkan berbagai macam penyakit ringan maupun berat, termasuk sebagai obat luka. Hampir semua bagian tanaman binahong seperti umbi, batang, bunga, dan daun dapat digunakan dalam terapi herbal. ${ }^{2}$

Luka adalah keadaan dimana kontinuitas jaringan rusak oleh karena trauma dari benda tajam atau tumpul, perubahan suhu, kimiawi, listrik, radiasi, atau gigitan hewan. ${ }^{3}$ Sebagai respon dari kerusakan jaringan tersebut, maka tubuh akan berusaha untuk memperbaiki jaringan yang rusak melalui mekanisme penyembuhan luka. Untuk membantu penyembuhan luka dapat menggunakan daun binahong.

Sebagai obat luka, binahong mengandung beberapa kandungan kimia yaitu flavonoid, asam oleanolik, protein, saponin, dan asam askorbat. Kandungan asam askorbat pada tanaman ini penting untuk mengaktifkan enzim prolil hidroksilase yang menunjang tahap hidroksilasi dalam pembentukan kolagen, sehingga dapat mempercepat proses penyembuhan luka. ${ }^{4}$

Berdasarkan uraian tersebut, peneliti tertarik melakukan penelitian untuk melihat khasiat daun binahong terhadap pembentukan jaringan granulasi dan reepitelisasi penyembuhan luka terbuka kulit kelinci secara makroskopik dan mikroskopik.

\section{METODE PENELITIAN}

Penelitian ini merupakan penelitian eksperimental laboratorik, dilakukan pada periode Oktober 2012 - Januari 2013 di Bagian Patologi Anatomi Fakultas Kedokteran Universitas Sam Ratulangi, Manado. Penelitian menggunakan lima ekor kelinci, satu ekor kelinci untuk melihat struktur jaringan kulit normal kelinci. Empat ekor kelinci dibuat luka pada punggung kanan diberikan daun binahong dan luka pada punggung kiri tidak diberikan daun binahong. Empat ekor kelinci ini dibagi dua kelompok, yaitu kelompok A sebanyak dua ekor kelinci yang diambil dan dilihat jaringan luka pada hari kelima, kelompok B sebanyak dua ekor kelinci yang diambil dan dilihat jaringan lukanya pada hari ke-14. Untuk setiap luka pada punggung kanan kelinci diberikan lima lembar daun binahong yang ditumbuk halus kemudian ditempel pada permukaan luka segera setelah di eksisi. Hal ini dilakukan sebanyak dua kali sehari yaitu pada pagi dan sore hari.

\section{HASIL PENELITIAN}

\section{Gambaran makroskopik}

Penyembuhan luka kulit kelinci pada hari kelima secara makroskopik (gambar 1) menunjukkan adanya perbedaan antara luka yang diberi daun binahong (panah hijau) dan tanpa pemberian daun binahong (panah biru). Luka yang diberi daun binahong terlihat lebih kering dan tepi luka sedikit menyatu, sedangkan yang tidak diberi daun binahong terlihat permukaan masih basah, merah dan terdapat sedikit bekuan darah.

Penyembuhan luka kulit kelinci pada hari ke-14 secara makroskopik (gambar 2) menunjukkan adanya perbedaan yang jelas antara luka yang diberi daun binahong (panah hijau) dan tanpa pemberian daun binahong (panah biru). Luka yang diberi 
daun binahong terlihat kering dan berukuran lebih kecil, sedangkan yang tidak diberi daun binahong terlihat luka masih dalam, kemerahan, tetapi tepi luka sudah kering.

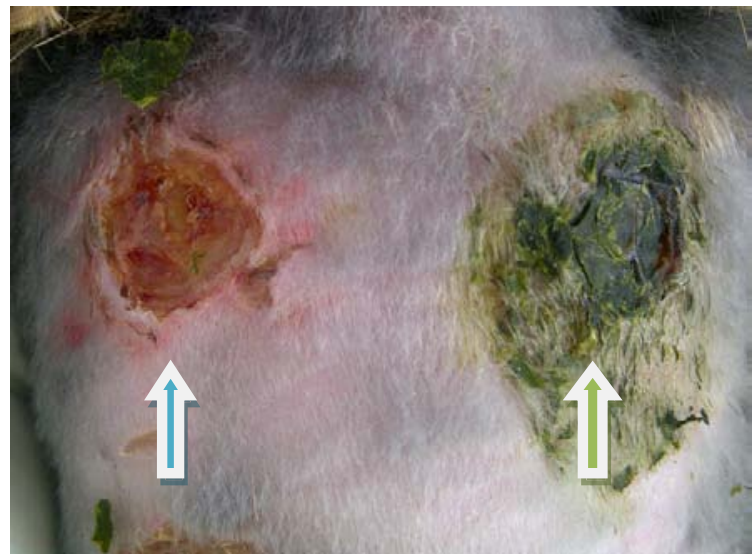

Gambar 1. Penyembuhan luka kulit kelinci hari kelima. Luka yang tidak diberi daun binahong (panah biru), luka yang diberi daun binahong (panah hijau).

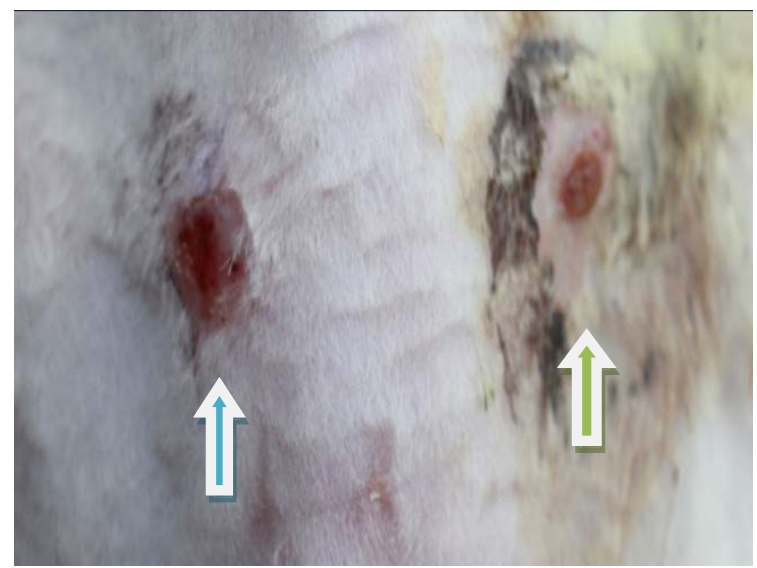

Gambar 2. Penyembuhan luka kulit kelinci hari ke-14 Luka yang tidak diberi daun binahong (panah biru), luka yang diberi daun binahong (panah hijau).

\section{Gambaran Mikroskopik}

Kulit normal terdapat lapisan epidermis, dermis, folikel rambut, dan adneksa kulit lainnya (Gambar 3).

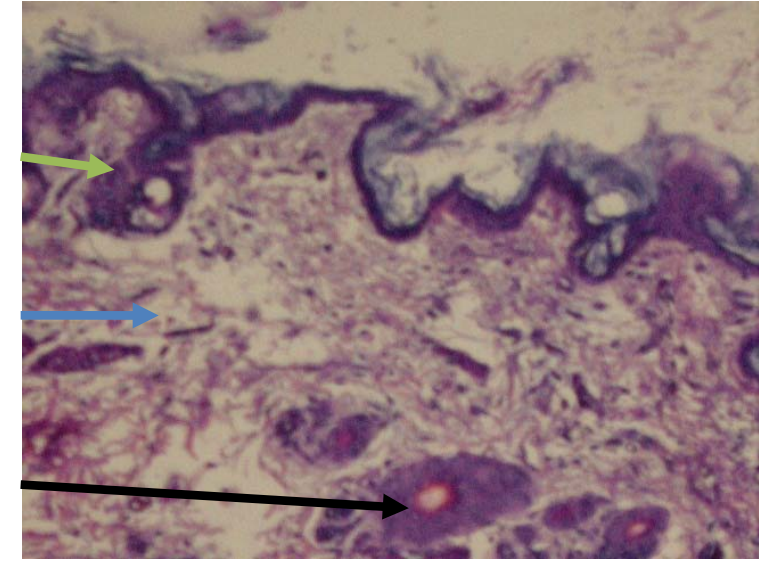

Gambar 3. Gambaran mikroskopik kulit normal kelinci, terdapat lapisan epidermis (panah hijau), dermis (panah biru), folikel rambut (panah hitam).

\section{Kelompok A (penyembuhan hari kelima)}

Kelompok tanpa perlakuan (tidak diberi daun binahong) tampak jaringan granulasi yang terdiri dari kapiler, fibroblast, dan sel-sel radang (Gambar 4).

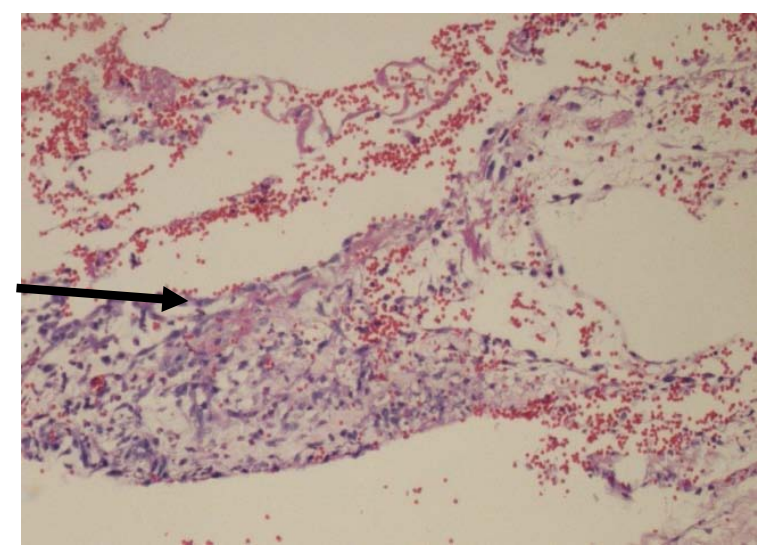

Gambar 4. Gambaran mikroskopik menunjukkan jaringan granulasi pada luka tanpa pemberian daun binahong.

Kelompok perlakuan (diberi daun binahong) tampak sel-sel radang dan jaringan granulasi lebih banyak (Gambar 5). 


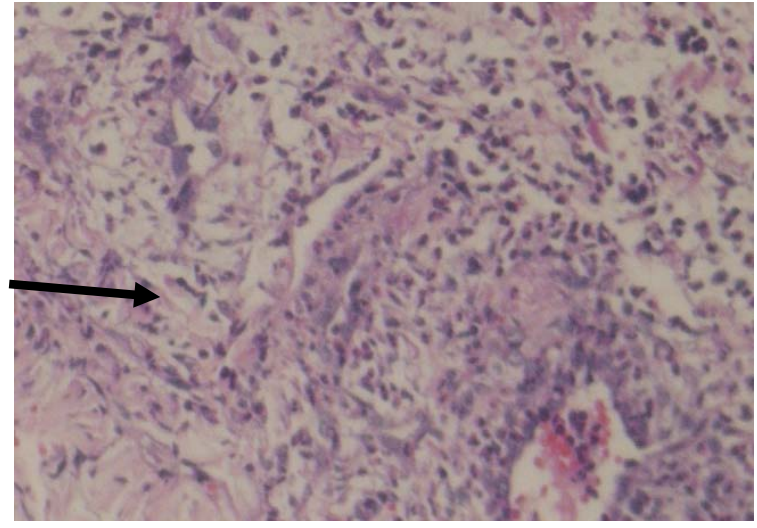

Gambar 5. Gambaran mikroskopik menunjukkan jaringan granulasi pada luka dengan pemberian daun binahong.

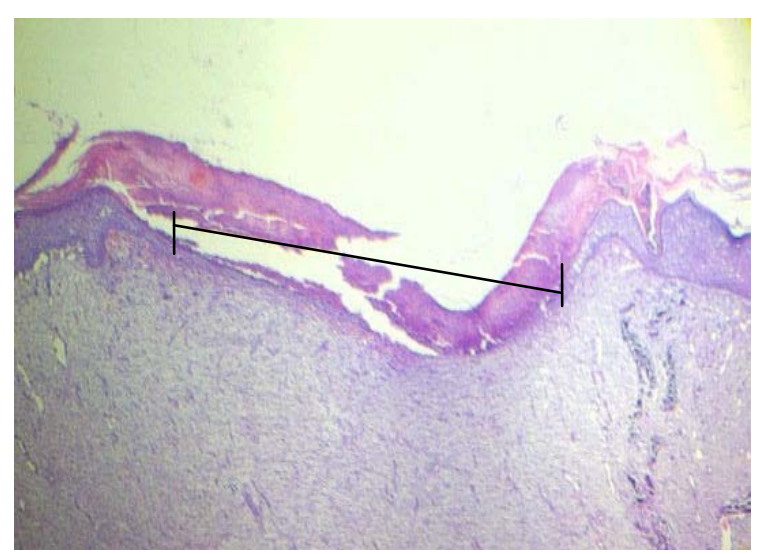

Gambar 6. Gambaran mikroskopik panjang luka yang masih terbuka pada luka tanpa pemberian daun binahong.

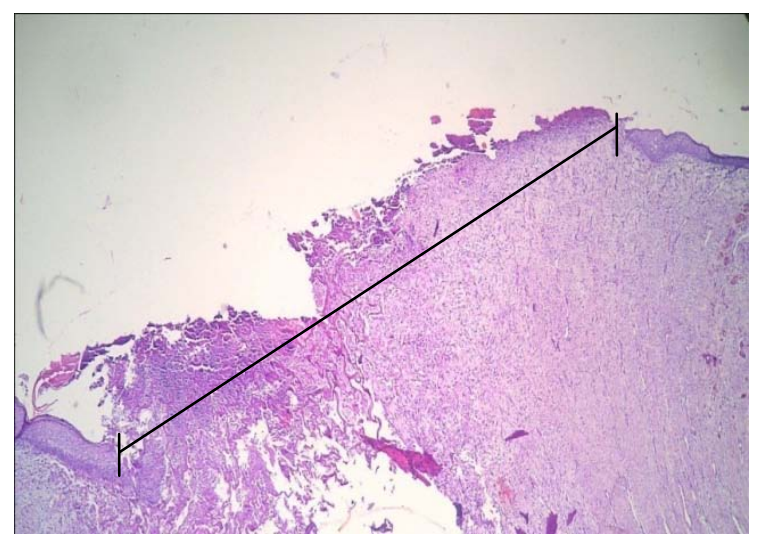

Gambar 7. Gambaran mikroskopik panjang luka yang masih terbuka pada luka dengan pemberian daun binahong.

\section{Kelompok B (penyembuhan hari ke-14)}

Kelompok tanpa perlakuan (tidak diberi daun binahong), panjang luka yang masih terbuka diukur dari ujung-ujung yang mengalami reepitelisasi yaitu $5 \mathrm{~mm}$ (Gambar 6).

Kelompok tanpa perlakuan (diberi daun binahong), panjang luka yang masih terbuka diukur dari ujung-ujung yang mengalami reepitelisasi yaitu 2,5 $\mathrm{mm}$ (Gambar 7).

\section{BAHASAN}

Pada kelinci kelompok A yang diperiksa hari ke-5 secara makroskopik (Gambar 3) menunjukkan sedikit perbedaan antara luka terbuka yang diberi dan tidak diberikan daun binahong. Luka yang diberi daun binahong terlihat lebih kering dan tepi luka mulai menyatu, sedangkan yang tidak diberi daun binahong terlihat permukaan masih basah, berwarna merah, terdapat sedikit bekuan darah dan juga tepi luka mulai menyatu. Secara mikroskopik, luka yang diberi daun binahong menunjukkan sel-sel radang, dan jaringan granulasi yang lebih banyak dibandingkan dengan luka tanpa diberi daun binahong (Gambar 4 dan 5). Hal ini sesuai teori penyembuhan luka yaitu pada hari ke-5 neovaskularisasi mencapai puncaknya karena jaringan granulasi mengisi ruang insisi, serabut kolagen menjadi lebih berlimpah dan mulai menjembatani insisi. Mula-mula bekuan darah mengisi luka dan anyaman fibrin terbentuk, granulosit dan monosit fagositik memulai proses pembersihan. Tunas kapiler dan fibroblast dengan cepat berproliferasi ke bekuan darah. Tunas kapiler mengeluarkan enzim litik untuk memecahkan fibrin dan memungkinkan pembentukan anyaman. Fibroblast yang berproliferasi menyertai pembuluh ini dan mulai menimbun kolagen. Pada fase proliferasi, 3 sampai 5 hari muncul jenis jaringan khusus yang mencirikan terjadinya penyembuhan, yang disebut jaringan granulasi. Istilah jaringan granulasi berasal 
dari gambaran makroskopisnya yang berwarna merah muda, lembut, dan bergranula, sedangkan gambaran histologisnya ditandai dengan proliferasi fibroblast dan kapiler baru yang halus dan berdinding tipis di dalam matriks ekstraselular yang longgar. Jaringan granulasi kemudian akan mengumpulkan matriks jaringan ikat secara progresif, yang akhirnya menghasilkan fibrosis padat, yang dapat melakukan remodeling lebih lanjut sesuai perjalanan waktu. Adapun faktor pertumbuhan yang berperan pada proses pemulihan jaringan yaitu Epidermal Growth Factor (EGF) berfungsi mitogenik keratinosit dan fibroblast, merangsang migrasi keratinosit dan pembentukan jaringan granulasi; Fibroblast Growth Factor (FGF) berfungsi kemostasis untuk fibroblast, merangsang angiogenesis, kontraksi luka dan deposisi matriks. Faktor pertumbuhan lainnya adalah PlateletDerived Growth Factor (PDGF); Transforming Growth Factor- $\beta$ (TGF- $\beta)$; Nerve Growth Factor (NGF). ${ }^{5,6}$

Kelinci kelompok B yang diperiksa pada hari ke-14, secara makroskopik (gambar 2) menunjukkan luka yang diberi daun binahong terlihat jelas lebih kering dan kecil, sedangkan yang tidak diberi daun binahong terlihat luka masih dalam, kemerahan, tetapi tepi luka sudah kering. Pada gambaran mikroskopik (gambar 6 dan 7) luka yang tidak diberi daun binahong terlihat fibroblas dan radang yang banyak, dan diukur panjang luka yang masih terbuka yaitu $5 \mathrm{~mm}$, sedangkan luka yang diberi daun binahong dilakukan pengukuran panjang luka yang masih terbuka yaitu 2,5 mm.

Penyembuhan luka pada hari ke-14 berada pada fase proliferasi, ditandai dengan adanya proliferasi sel/pembelahan sel. Peningkatan jumlah fibroblast pada daerah luka merupakan kombinasi dari proliferasi dan migrasi. Fibroblast ini berasal dari sel-sel mesenkimal lokal, terutama yang berhubungan dengan lapisan adventisia, pertumbuhannya disebabkan oleh sitokin yang diproduksi oleh makrofag dan limfosit. Fibroblast merupakan elemen utama pada proses perbaikan untuk pembentukan protein struktural yang berperan dalam pembentukan jaringan. Peran fibroblast sangat besar untuk menghasilkan struktur protein yang digunakan selama proses rekontruksi jaringan baru. Pemulihan jaringan tidak hanya bergantung pada faktor pertumbuhan, namun juga bergantung pada interaksi antara sel dan komponen matriks ekstraseluler. Matriks ekstraselular merupakan kompleks makromolekuler yang dinamis dan terus mengalami perubahan bentuk secara konstan dan disintesis secara lokal, berkumpul menjadi suatu jejaring yang mengelilingi sel. ${ }^{6,7}$

Penelitian ini menunjukkan bahwa terdapat perbedaan pembentukan jaringan granulasi dimana pada kelompok perlakuan dengan daun binahong, jaringan granulasi lebih banyak dan krusta lebih tebal dibandingkan dengan kelompok tanpa perlakuan. Hal tersebut membuktikan daun binahong berperan dalam penyembuhan luka, dimana kandungan zat flavonoid bertanggung jawab melalui mekanisme antiinflamasi, penghambatan aktivitas radikal bebas, dan meningkatkan kecepatan epitelisasi, kandungan asam askorbat menunjang pembentukan kolagen, dimana segera setelah luka, paparan kolagen fibriler ke darah akan menyebabkan agregasi dan aktivasi trombosit dan melepaskan faktor-faktor kemotaksis yang memulai proses penyembuhan luka. Fragmen-fragmen kolagen melepaskan kolagenase leukositik untuk menarik fibroblas ke daerah luka. Selanjutnya kolagen menjadi pondasi untuk matrik ekstraseluler yang baru, sehingga mempercepat pembentukan jaringan granulasi, dan kandungan saponin pada daun binahong mencegah terjadinya infeksi pada luka. ${ }^{7,8}$

\section{SIMPULAN}

Pada penelitian ini didapatkan perbedaan yang jelas antara penyembuhan luka yang diberi daun binahong dan yang tidak diberi daun binahong yaitu 
pembentukan jaringan granulasi yang lebih banyak dan reepitelisasi terjadi lebih cepat dengan menggunakan daun binahong dibandingkan dengan tidak menggunakan daun binahong.

\section{UCAPAN TERIMA KASIH}

Ditujukan kepada dr. Sonny Kalangi, MBiomed, PA dan dr. Poppy Lintong, Sp.PA (K) selaku penguji, serta kepada semua pihak yang baik secara langsung dan tidak langsung telah menumbuhkan ide atau gagasan pada penulis sehingga penulis dapat menyelesaikan artikel ini.

\section{DAFTAR PUSTAKA}

1. Shabella R. Terapi Daun Binahong Cetakan 1. Klaten: Cable Book, 2012; p.10.

2. Rofadia K. Penggunaan Beberapa Jenis Sitokinin Terhadap Multiplikasi Tunas Dan Pertumbuhan Binahong Anredera cordifolia [Ten.] Steenis) secara IN
VITRO. [Skripsi]. Bogor: Fakultas Kehutanan. Institut Pertanian Bogor, 2009.

3. Reksoprodjo S. Kumpulan Kuliah Ilmu Bedah. Jakarta: Fakultas Kedokteran Universitas Indonesia, 2012; p.387.

4. Susetya D. Khasiat \& Manfaat Daun Ajaib Binahong Cetakan 1. Yogyakarta: Pustaka Baru Press, 2012; p.25.

5. Cruse PJE, Mcphedran NT. Penyembuhan dan Penatalaksanaan Luka. In: Sabiston, editor. Buku Ajar Bedah bagian 1. Jakarta: EGC, 1992; p.145.

6. Robbins and Cotran. Pathology of disease (Eigth Edition). Philadelphia: Saunders Elsevier, 2010; p 65-68.

7. Mercandetti M, Cohen A. Wound healing, healing and repair [homepage on the Internet]. Nodate [cited 2012 Sep 29]. Available from: URL: http://www.eMedicine .com.Inc.

8. Triyono B. Perbedaan Tampilan Kolagen Di Sekitar Luka Insisi Pada Tikus Wistar Yang Diberi Infiltrasi Penghilang Nyeri Levobupivakain Dan Yang Tidak Diberi Levobupivakain [Tesis]. Semarang: Universitas Diponegoro; 2005. 